\title{
Öğretim Elemanlarının Algıladıkları Psikolojik Sözleşme İhlalleri, Örgüte Bağlılık ve İşsten Ayrılma Niyetleri Üzerine Bir Araştırma*
}

\author{
A Study on Psychological Contract Violation, Organizational Commitment and Intention to Leave Perceived by \\ Academic Staff \\ Halime Göktaş Kulualp ${ }^{\mathrm{a}}$, Doğan Karadağ
}

${ }^{a}$ Dr. Öğr. Üyesi, Karabük Üniversitesi, Safranbolu Turizm Fakültesi, Turizm İşletmeciliği Bölümü, 78600, Karabük/Türkiye. ORCID: 0000-0002-1485-3026.

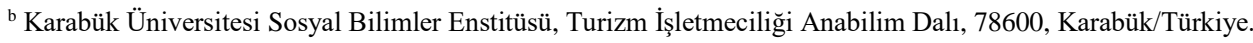
ORCID: 0000-0003-1174-2442.

\section{MAKALE BİLGİṠ \\ Makale Geçmişi: \\ Başvuru tarihi: 01 Şubat 2019 \\ Düzeltme tarihi: 08 Mayıs 2019 \\ Kabul tarihi: 29 Mayıs 2019}

\section{Anahtar Kelimeler:}

Psikolojik Sözleşme

Psikolojik Sözleşme İhlal Algısı,

Örgüte Bağlılık

İşten Ayrılma Niyeti

Öğretim Elemanları

\section{A R T I C L E IN F O}

\section{Article history:}

Received 01 February 2019

Received in revised form 08 May 2019

Accepted 29 May 2019

\section{Keywords:}

Psychological Contract

Perception of Psychological Contract

Violation

Organizational Commitment

Intention to Leave
ÖZ

Çalışma koşullarındaki hızlı değişimler, çalışanların işine karşı algılarının hassaslaşmasına neden olmuştur. Bu hassas dönemde, çalışanı elde tutma yollarından biri de yazısız sözleşmeler olarak bilinen psikolojik sözleşmelerdir. Psikolojik sözleşmeler, çalışanların örgütlerine olan bağlılıklarını etkilemektedir. Bu bağlamda psikolojik sözleşme ihlal algılarının akademisyenler üzerinde örgüte bağlllık ve işten ayrılma niyetine etkilerini belirlemek için tesadüfi yöntemle Karadeniz bölgesinde bulunan 3 üniversite belirlenmiş ve bu üniversitelerin akademik personeline online anket uygulanmıștır.Yapılan analizler sonucunda algılanan psikolojik sözleşme ihlallerinin örgüte bağl1lık ve işten ayrılma niyeti üzerinde anlamlı bir etkisi olduğu saptanmıştır. Ayrıca algılanan psikolojik sözleşme ihlallerinin örgütsel bağlılığın alt boyutlarından olan duygusal bağlılık ve devamlılık bağlılığı üzerinde anlamlı bir etkisinin olduğu saptanmış fakat bir diğer alt boyut olan normatif bağl1lık üzerinde istatistiki olarak anlamlı bir etkisi bulunamamıştır.

\section{A B S T R A C T}

Rapid changes in working conditions affect the sensitivity of employees to work. Psychological contracts are important in this sensitive period. So, an online questionnaire was applied to the academic staff of 3 Black Sea universities which were determined by random methods in order to determine the effects of perceptions of violations of psychological contract on the commitment of the organization and intention to leave. According to the research results, it was determined that the perceived of psychological contract violations had a significant effect on the organizational commitment and the intention to leave. In addition, it was determined that the violations of perceived psychological contract had a significant effect on the commitment of emotional commitment and continuity.

\section{Giriş}

Teknolojinin gelişimi, rekabetin artması, piyasa koşullarının sürekli olarak değişim göstermesi ve bilgi elde etme sürecinin hılanması gibi nedenlerle örgütlerin ekonomilerinde, mikro ve makro çevrelerinde bazı

değişimler meydana gelmiştir. Hızlanan küreselleşme sürecinde, örgütlerin bulundukları pazarda varlıklarını

\footnotetext{
* Bu çalışma, 12-14 Eylül 2018 tarihlerinde Karabük’te düzenlenen International Business and Organization Conference (BOR) adlı sempozyumda, "Psikolojik Sözleşme İhlallerinin Örgütsel Bağlılık ve İşten Ayrılma Niyeti Üzerindeki Etkileri: Akademisyenler Üzerinde Bir Çalışma" adlı başlıkla sunulmuştur.

**Sorumlu Yazar/Corresponding author

e-posta: halimegoktas@karabuk.edu.tr
} 
sürdürebilmeleri ve belirledikleri hedeflere ulaşabilmeleri için kendi alanlarında yetenekli, bilgili ve değişimlere ayak uydurabilecek işgörenlere olan ihtiyaçları artış göstermiştir. Örgüt yapılarında meydana gelen bu değişim ve gelişmelerin oluşturduğu karmaşıklık işgörenler üzerinde olumsuz sonuçlara neden olmuştur. Bu durum, işgörenlerin işlerine ve örgütlerine karşı bir yabancılaşma yaşamalarına (İyigün, 2011, 2) neden olmuş ve örgüte bağl1lık ve motivasyonlarının (Dabos ve Rousseau, 2004) azalmasına, sadakat ve güven duygularının (Krivokapic-Skoko, ONeill ve Dowell, 2011) zarar görmesine yol açmıştır.

Esneklik, işgörenlerin özgüveni, uyumun önem kazanması ile ortaya çıkan yani istihdam yapısında istikrar, adalet, gelenekler ve görenekler gibi özelliklerin önemini kaybetmesi ile örgütlerdeki psikolojik sözleşmelerde de değişiklik göstermektedir (Özyılmaz, 2016, 186). Meydana gelen bu değişimler işgörenin, işe ve örgüte olan bağlılıklarının azalması, iş ahlakının ve etiğinin bozulması, mesleki bağımlılığının artması olarak ifade edilebilir. Psikolojik sözleşmelerde oluşan bu değişimlerin nedeninin, örgüt yapısında oluşan yataylaşma ve kıdem değişimleri ile birlikte iş güvenliği garantisinde azalma olduğu tahmin edilmektedir (Cihangiroğlu ve Bayram, 2012, 4).

Yapılan literatür incelemesi neticesinde banka çalışanları, otel çalışanları, hastane çalışanları vb. sektör çalışanları ile psikolojik sözleşme ihlalleri üzerinde yapılan çalışmalara rastlanılmıştır (Büyükyılmaz ve Çakmak, 2014: 584). Fakat akademik personel ile yapılan çalışmaların sınırlı sayıda olduğu görülmüştür (Aydın vd., 2008; Dabos ve Rousseau, 2004; Orvis vd., 2008; Tipples vd., 2007). Akademik personelin görevlerini yaparken olumsuz düşünce ve olaylardan uzak kalması eğitim kalitesi açışından oldukça önemli bir unsurdur. Akademik personel ve üniversite yönetimleri arasında meydana gelebilecek olumsuzlukların belirlenerek gün yüzüne çıkarılabilmesi için bu çalışma gerçekleştirilmiştir. Bu çalışma psikolojik sözleşmenin, akademik personel üzerinde örgüte bağlılık ve işten ayrılma niyetlerini nasıl etkilediğini belirlemek için hazırlanmıştır.

Bu kapsamda Türkiye'nin Karadeniz bölgesinde bulunan ve tesadüfi yöntem ile belirlenen 3 üniversitede görev yapmakta olan akademisyenlere mail aracılığıyla anket uygulanmıştır. Çalışmanın birinci bölümünde literatür bilgisine yer verildikten sonra ikinci ve üçüncü bölümde literatür bilgileri 1şığında oluşturulan hipotezler ve analiz sonuçları sunulmuştur. Son olarak elde edilen bulgular değerlendirilerek konu ile ilgili öneriler hazırlanmıştır.

\section{Literatür Taraması}

İnsan, doğası gereği davranışlarının anlaşılması ve yorumlanması oldukça zor bir varlıktır. Bu durum, insan davranışlarının ve hareketlerinin önceden tahmin edilmesini zorlaştırmaktadır. Fakat araştırmacılar örgütlerde ve sosyal yaşam alanlarında insan davranışlarını açıklayabilmek ve anlayabilmek adına, bu davranışları bir bilim dalı olarak ele alarak işletmecilik, sosyoloji, psikoloji ve davranış bilimlerinden de yararlanarak çok sayıda teori, kuram, teknik ve kavram ortaya koymuşlardır. Örgüte bağlılık, psikolojik sözleşme ve işten ayrılma niyeti bu kavramlar arasında yer almaktadır (İşçi, 2010:2). Tarih boyunca insanlar günlük yaşantılarında sosyal çevreleri ile iletişim içinde bulunmuştur. İletişimin var olduğu her an, insanlar birbirleri ile psikolojik bir bağ kurarlar ve bu bağ gerek günlük yaşantıda ve gerekse organizasyonlar için işlerin yürütülebilmesinde çok önemlidir (Dağl1, 2016: 4). Var olan bu psikolojik bağ literatürde psikolojik sözleşme olarak yer almaktadır. İşçi-işveren arasındaki ilişkileri açıklamak için bu kavramı ilk kez kullanan Argyris (1960) psikolojik sözleşmeyi "iki taraf arasında, birbirlerinin normlarına saygılı olmaya yönelik, örtük ve yazılı olmayan anlaşma" şeklinde tanımlamıştır (aktaran: Cihangiroğlu ve Şahin, 2010:2; aktaran: Özgen ve Özgen, 2010:2). Kotter (1973) ise bu kavramı "kişi ve içinde bulunduğu örgüt arasında sözle ifade edilmeyen, kapalı, tarafların iş ilişkileri içerisinde birbirlerine vermeyi ve birbirlerinden almayı bekledikleri psikolojik yönü bulunan anlaşmadır" (aktaran: Özgen ve Özgen, 2010: 2) şeklinde ifade etmektedir. İşveren ve çalışan arasında yapıldığı varsayılan, tarafların birbirlerine olan beklentilerini aktaran bu yazılı olmayan sözleşme türü, örgüt içinde motivasyon sağlayan bir fonksiyondur. Karşılıklı olarak beklentilerin karşılanmaması durumunda ise çalışan ve işveren açışından dengeler değişecek ve örgüt içindeki bağlılığ ve çalışma isteğini ortadan kaldıracaktır (Kaldırımcı, 1987: 118-119). Yılmaz (2012: 8-9)'a göre psikolojik sözleşmelerin bazı ortak özellikleri şu şekildedir:

- İşveren ve çalışan arasında yapılan bu sözleşme alg1 temeline dayanır ve yazılı kurallar yoktur,

- Bireyseldir ve karşılıklı faydaya dayanmaktadır,

- Biçimsel değil ilişkisel bir özelliği vardır,

- Çalışan ve işveren arasında bir bağlılık vardır ve zaman içerisinde değişime uğrayabilir bundan dolayı dinamik bir yapıya sahiptir,

- Anlaşmanın temelini ve içeriği duygusal beklentiler ve yükümlülükler yoğun bir şekilde oluşturmaktadır.

Resmi yazılı olan sözleşmeler ve psikolojik sözleşmeler arasında birtakım farklar ve özellikler bulunmaktadır. Morrison (1994)'a göre psikolojik sözleşmenin bazı özellikleri şu şekildedir;

- Psikolojik sözleşmelerde var olan beklentiler sözlü olarak belirtilmemekte ve tamamen algılara dayanmaktadır,

- Psikolojik sözleşmede beklentiler kişi ve örgütlerin geçmiş deneyimlerine dayanır ve bu yönde gelişir,

- Psikolojik sözleşmede bulunan taraflar birbirlerine bağımlıdırlar,

- Psikolojik sözleşmelerin yapıldığı taraflar arasında bazı psikolojik mesafeler oluşur,

- Psikolojik sözleşmeler yapıları gereği dinamiktir (Özler ve Ünver,2012: 329).

İşverenlerin ve çalışanların karşılıklı olarak bazı beklentileri vardır. Fakat sürekli olarak verilen vaatler, beklentiler ve bunların meydana getirdiği yükümlülükler gerçekleştirilemeyebilir. Psikolojik sözleşmeler ile birlikte yerine getirilemeyen bu yükümlülükler literatürde psikolojik sözleşmelerde ihlal başlığı altında 
incelenmektedir (Büyükyılmaz ve Çakmak, 2014: 583). Morrison ve Robinson'ın (1997:228) psikolojik sözleşme ihlalini çalışanlar yönü ile inceleyerek yaptığı tanıma göre; psikolojik sözleşme ihlali, çalışanın örgüte yaptığı katkılara karşılık olarak örgütün veya işverenin çalışana karş1 yükümlülüklerini yerine getirmedikleri düşüncesidir (aktaran: Torun ve Üçok, 2014: 234). Yapılan bir diğer tanıma göre ise psikolojik sözleşme ihlali, çalışanın ya da ișverenin karşı tarafa olan yükümlülüklerini veya verilen vaatlerin yerine getirilememesidir (Doğan ve Demiral, 2009: 55).

İş hayatında psikolojik sözleşme ihlalleri sıkça görülmektedir. $\mathrm{Bu}$ ihlallerin çalışanın memnuniyet düzeyini, örgütsel bağlılığını, performanslarını azaltmaktadır ve işten ayrılma isteğine yol açmaktadır (Dabos ve Rousseau, 2004; Krivokapic-Skoko, ONeill ve Dowell, 2011). Meyer ve Allen (1996) yaptıkları çalışmalar sonucunda örgütsel bağlılığı, çalışanların örgütle girdikleri etkileşim doğrultusunda örgütün sürekli bir üyesi olma kararlarını geliştiren, psikolojik boyuta sahip bir davranış türü olduğunu belirtmişlerdir. Swailes (2002), örgüte bağlılıkta bulunan temel faktörleri şu şekilde açıklamaktadır;

- Örgütün sahip olduğu amaçlara ve değerlere inanarak kabullenme,

- Örgüt menfaatleri doğrultusunda tüm çabalarını ortaya koymaya gönüllü olma,

- Örgütün bir üyesi olabilmek için güçlü bir irade göstermek (aktaran: Durna ve Eren, 2011: 211).

Örgüte bağlılık ile ilgili yapılan çalışmalar (Etzioni 1961; O'Reilly ve Chatman, 1986; Meyer ve Allen 1984; Becker 1960), bağlilığın tutumsal veya davranışsal bir temele dayandığını belirtmektedir. Bu nedenle bağlılık; davranışsal ve tutumsal olmak üzere iki ana başlık altında incelenmektedir (Bayram, 2005, 129). Davranışsal bağlılık, çalışanın davranışlarından kaynaklanırken, tutumsal bağlılık ise çalışanın örgüt amaçları ile özdeşleşmesini ve bu amaçlar doğrultusunda çalışma isteğinden kaynaklanmaktadır (Karataş ve Güleş, 2010, 77).

Çalışanlar, örgütün ve beraberinde kendilerinin elde edebilecekleri muhtemel başarılara bakarak bir değerlendirmede bulunurlar. Elde edebilecekleri başarıları yeterli görürlerse işten ayrılma niyeti taşımazlar fakat beklenen başarılar düşük ise verimliliklerinde düşüşler yaşanabilir ve bu da örgüte olan bağlılıklarını azaltarak, örgüt dışı iş firsatlarına yönelmelerine sebep olabilmektedir (Polat ve Meydan, 2010, 153). Psikolojik sözleşme ve örgüte bağlılık arasındaki ilişki işten ayrılma niyeti ile doğru orantılıdır. Çalışanlar psikolojik sözleşmeyi olumlu bir şekilde algılıyorlar ise işten ayrılma niyetleri düşecektir. Örgütsel bağlılığı, düşük olan çalışanların, bağlılığı yüksek olan çalışanlara göre daha fazla devamsızlık göstermekte ve örgütten ayrılma niyeti taşımaktadırlar, bu da yüksek iş gücü devrini beraberinde getirmektedir (Kama ve Poyraz, 2008, 148; Özgen ve Özgen, 2010, 6).

\section{Araştırma Yöntemi}

\subsection{Araştırma Örneklemi ve Ölçekler}

Bu çalışma, psikolojik sözleşme ihlallerinin akademik personeller üzerinde örgüte bağlılık ve işten ayrılma niyeti üzerindeki etkilerini belirlemek üzere oluşturulan bir alan araştırmasıdır. Araştırmada veri toplama amacıyla anket tekniği kullanılmıştır. Çalışmanın evrenini, Türkiye'nin Karadeniz bölgesinde bulunan üniversitelerde eğitim vermekte olan akademik personeller oluşturmaktadır. Ancak, araştırmacı için zaman ve imkan kısıtı bulunduğundan dolayı örnekleme seçilmesi uygun görülmüş ve bu üniversiteler arasından tesadüfi yöntemle üç üniversite belirlenmiştir. Belirlenen 3 üniversitede toplam 2288 akademik personel bulunmaktadır. Sekaran (2003)'e göre bu evren büyüklüğünü en iyi temsil edecek örneklem sayıs1 327'dir. Bu üç kamu üniversitesinde bulunan akademisyenlere online anket düzenlenmiş ve 324 geçerli anket elde edilmiştir.

Yapılan çalışma kapsamında psikolojik sözleşme ihlallerini belirlemek için orijinali Robinson ve Rousseau (1994) tarafından geliştirilen 9 maddeli "Psikolojik sözleşme ihlali" ölçeği kullanılmıştır. İşten ayrılma niyetini belirlemek amaciyla Polat ve Meydan (2010) ve Alper Bahadır Dalmış (2018)'ın çalışmalarında kullandıkları 5 maddeli işten ayrılma niyeti ölçeği kullanılmıştır. Örgütsel bağlılığı belirlemek amaciyla ise Meyer ve Allen (1997) tarafından geliştirilen 16 maddeli ölçek kullanılmıştır. Çalışmada değişkenlerin etki dereceleri belirlemek için 5'li likert ölçeği (1: Kesinlikle katılmıyorum, .......3: Kararsızım..... 5: Kesinlikle katılıyorum) kullanılmıştır.

Araştırmada analiz yöntemi olarak, ölçeklerin geçerlilik ve güvenilirlik analizleri, değişkenler arası ilişki olup olmadığını tespit etmek amacıyla korelasyon analizi, faktör yapılarını belirlemek amaciyla faktör analizleri ve değişkenler arası etkileşim durumunu belirlemek amacıyla regresyon analizi uygulanmıştır.

\subsection{Araştırma Modeli ve Hipotezler}

Yapılan literatür taramasına bağlı kalınarak, araştırma kapsamında hazırlanan model ve kurulan hipotezler şu şekildedir:

H1: Psikolojik sözleşme ihlal algısının örgüte bağlılık üzerinde negatif yönlü ve anlamlı bir etkisi vardır.

H2: Psikolojik sözleşme ihlal algısının duygusal bağlılık üzerinde negatif yönlü ve anlamlı bir etkisi vardır.

H3: Psikolojik sözleşme ihlal algısının devamlılık bağlılığı üzerinde negatif yönlü ve anlamlı bir etkisi vardır.

H4: Psikolojik sözleşme ihlal algısının normatif bağlılık üzerinde negatif yönlü ve anlamlı bir etkisi vardır.

H5: Psikolojik sözleşme ihlal algısının işten ayrılma niyeti üzerinde pozitif yönlü ve anlamlı bir etkisi vardır.

\section{Şekil 1: Araştırma Modeli}




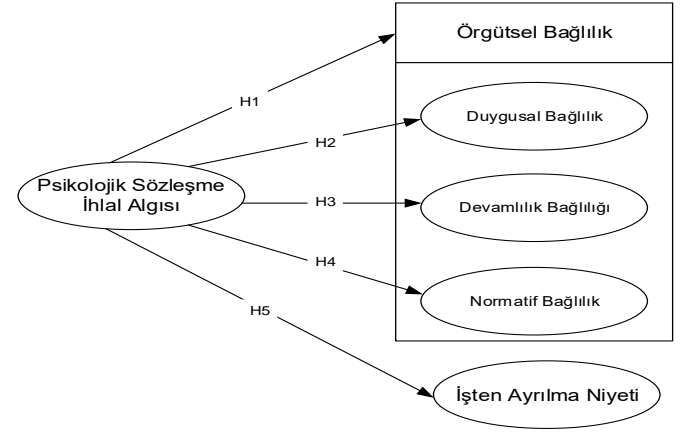

\section{Bulgular ve Analizler}

\subsection{Demografik Bilgiler}

Demografik bilgilere ait Tablo 1 incelendiğinde, katılımcıların 122'sinin (\%37,7) 24-34 yaş aralığında 6 'sının (\%9) ise 24 yaş ve altında olduğu görülmektedir. Katılımciların 164'ü $(\& 50,6)$ kadın ve 151'i $(\% 46,6)$ erkektir. Araştırmaya dâhil olan katılımcıların 231'i $(\% 71,3)$ evli iken 85 'i $(\% 26,2)$ bekardır. Araştırmanın yapıldığı dönem içerisinde katılımcıların bulundukları kurumda çalışma süreleri incelendiğinde katılımcıların 138' $(\% 42,6) 5$ yıl ve altı, 17 'si $(\% 5,2)$ ise $16-20$ yıl aralı̆̆ında olduğu görülmektedir. Son olarak da katılımcıların 140'1 $(\% 43,2)$ yurtdışında 1 yıl ve altında, 1 katılımcının $(\%, 3)$ $11-15$ yıl aralığında ve $1(\% 3)$ katılımcının ise 16 yıl ve üstünde yurtdışında bulunduğu belirlenmiştir.

Tablo 1: Katılımcılara Ait Frekans Değerleri

\begin{tabular}{|c|c|c|c|c|}
\hline $\begin{array}{l}\text { Demografik } \\
\text { Bilgiler }\end{array}$ & $\mathbf{N}$ & & $\begin{array}{l}\text { Frekans } \\
\text { (F) }\end{array}$ & $\begin{array}{l}\text { Yüzde } \\
(\%)\end{array}$ \\
\hline & & 24 yaş ve altı & 6 & 1,9 \\
\hline \multirow[t]{4}{*}{ Yaşınız } & & $25-34$ & 122 & 37,7 \\
\hline & & $35-44$ & 97 & 29,9 \\
\hline & 316 & $45-54$ & 69 & 21,3 \\
\hline & & 55 yaş ve üstü & 22 & 6,8 \\
\hline \multirow{2}{*}{ Cinsiyet } & & Kadın & 164 & 50,6 \\
\hline & 315 & Erkek & 151 & 46,6 \\
\hline \multirow{3}{*}{$\begin{array}{l}\text { Medeni } \\
\text { Durumunuz }\end{array}$} & & Evli & 231 & 71,3 \\
\hline & 316 & Bekâr & 85 & 26,2 \\
\hline & & 5 yıl ve alt1 & 138 & 42,6 \\
\hline \multirow[t]{5}{*}{$\begin{array}{l}\text { Bulunulan } \\
\text { Kurumda } \\
\text { Çalışma } \\
\text { Süresi }\end{array}$} & & 6-10 y1l aras1 & 105 & 32,4 \\
\hline & & $11-15$ y1l aras 1 & 22 & 6,8 \\
\hline & & $16-20$ y1l aras 1 & 17 & 5,2 \\
\hline & 316 & 21 y1l ve üstü & 34 & 10,5 \\
\hline & & 1 yll ve alt1 & 140 & 43,2 \\
\hline \multirow[t]{4}{*}{$\begin{array}{l}\text { Yurtdışında } \\
\text { Bulunma } \\
\text { Süresi } \\
\end{array}$} & & $2-5$ y1l aras1 & 19 & 5,9 \\
\hline & & 6-10 y1l aras1 & 8 & 2,5 \\
\hline & 169 & $11-15$ y1l aras 1 & 1 & 0,3 \\
\hline & & 16 y1l ve üstü & 1 & 0,3 \\
\hline
\end{tabular}

\subsection{Faktör ve Güvenilirlik Analizi}

Araştırmada kullanılan veri setinin faktör analizi için uygunluğunu belirlemek amaciyla test sonucunda KaiserMeyer-Olkin (KMO) değeri 0,937 Bartlett's test of sphericity " $p$ "değeri $(p<0,05)$ ise $0,000 *$ olarak belirlenmiştir. KMO değeri 0,90 'den büyük ve Bartlett's anlamlılık değeri 0,05 'ten küçük olduğu için veri seti analizler için uygundur (Kayış, 2017; Durmuş ve diğerleri, 2016).

Tablo 2: Güvenirlilik Düzeyleri

\begin{tabular}{cc}
\hline Faktör & Güvenirlilik Düzeyi \\
\hline Psikolojik Sözleşme İhlal Algısı & 0,913 \\
\hline Örgütsel Bağll1ık & 0,852 \\
\hline İşten Ayrılma Niyeti & 0,907 \\
\hline
\end{tabular}

Faktör analizinde soru ifadeleri arası korelasyonların 0,3 'ten yüksek olması beklenen bir durumdur, önerilen ise 0,4'ten büyük olmasıdır (Eisen vd., 1979; Yaşlığlu, 2017).

Tablo 3: Psikolojik Sözleşme İhlal Algısı Faktör Analizi Sonuçları

\begin{tabular}{|c|c|c|c|}
\hline $\begin{array}{l}\text { Psikolojik } \\
\text { Sözleşme İhlal } \\
\text { Algısı }\end{array}$ & Faktör Yükü & Ortalama & $\begin{array}{l}\text { Açıklanan } \\
\text { Varyans (\%) }\end{array}$ \\
\hline İfade1 & 0,724 & 3,35 & \multirow{9}{*}{53,938} \\
\hline İfade2 & 0,498 & 4,21 & \\
\hline İfade3 & 0,687 & 3,72 & \\
\hline İfade4 & 0,805 & 3,69 & \\
\hline İfade5 & 0,675 & 3,86 & \\
\hline İfade6 & 0,793 & 3,51 & \\
\hline İfade7 & 0,814 & 3,16 & \\
\hline İfade8 & 0,830 & 3,37 & \\
\hline İfade9 & 0,725 & 3,59 & \\
\hline
\end{tabular}

İfade 1: Çalıştı̆ım kurum, terfi veya yükselme programım hakkındaki sözlerini yerine getirmiştir.

İfade 2: İşimin ve çalışıı̆ıım işyerinin yapısı aynen kurumun söz vermiş olduğu gibidir.

İfade 3: Çalıştığım kurum performansla ilgili geribildirim ve değerlendirmeler konusunda verdiği sözlerini yerine getirmiştir.

İfade 4: Çalıştığım kurum, iş güvenliğimin seviyesini olduğundan farklı göstermemiştir.

İfade 5: Çalıştığım kurum, sorumluluk alma ve kendimi gösterme firsatlarım ile ilgili sözlerini yerine getirmiştir

İfade 6: Çalıştığım kurum, kişisel eğitimim ve gelişimim ile ilgili sözlerini yerine getirmiştir.

İfade 7: Çalıştığım kurum, değişim yönetimi sürecinde çalışanların rolünü yeterince takdir etmiştir

İfade 8: Çalıştığım kurum, kendisinin ya da çalışanlarının uzmanlığını, çalışma tarzını veya itibarını olduğundan farklı göstermemiştir

İfade 9: Çalıştı̆̆ım kurum, maaş, kazançlar ve ikramiyeler ile ilgili yükümlülüklerini yerine getirmiştir. 
Elde edilen birinci faktör olan "Psikolojik Sözleșme İhlal Algısı" 9 ifadeden oluşmaktadır. Belirlenen faktöre ait ifadeler toplam varyansın $\% 53,938$ 'sini açıklamaktadır.

Tablo 4: Örgüte Bağlılık Faktör Analizi Sonuçları

\begin{tabular}{|c|c|c|c|}
\hline Faktör & Faktör Yükü & Ortalama & $\begin{array}{c}\text { Açıklanan } \\
\text { Varyans }\end{array}$ \\
\hline \multicolumn{4}{|c|}{ Duygusal Bağlılık } \\
\hline İfade 1 & 0,841 & 3,85 & \multirow{7}{*}{36,301} \\
\hline İfade 2 & 0,860 & 3,78 & \\
\hline İfade 3 & 0,761 & 3,58 & \\
\hline İfade 4 & 0,878 & 3,57 & \\
\hline İfade 5 & 0,810 & 3,44 & \\
\hline İfade 6 & 0,653 & 3,72 & \\
\hline İfade 7 & 0,670 & 3,39 & \\
\hline \multicolumn{4}{|c|}{ Normatif Bağl1lık } \\
\hline İfade 1 & 0,397 & 3,54 & \multirow{5}{*}{14,487} \\
\hline İfade 2 & 0,748 & 3,17 & \\
\hline İfade 3 & 0,579 & 2,39 & \\
\hline İfade 4 & 0,701 & 3,11 & \\
\hline İfade 5 & 0,647 & 3,09 & \\
\hline \multicolumn{4}{|c|}{ Devamlılık Bağlılığı } \\
\hline İfade 1 & 0,728 & 2,62 & \multirow{4}{*}{5,611} \\
\hline İfade 2 & 0,736 & 2,60 & \\
\hline İfade 3 & 0,585 & 2,98 & \\
\hline İfade 4 & 0,508 & 3,34 & \\
\hline
\end{tabular}

\section{Duygusal Bă̆lllık}

İfade 1: Bu okula karşı duygusal bağ hissediyorum.

İfade 2: Bu okul benim için çok önem ve anlam taşıyor.

İfade 3: Çalıştığım okuldan dışarıda gururla bahsediyorum.

İfade 4: Okuluma karşı güçlü bir aidiyet duygusu hissediyorum.

İfade 5: $\mathrm{Bu}$ okulda kendimi ailenin bir parçası gibi hissediyorum.

İfade 6: Okulun problemlerini kendi problemim gibi hissediyorum.

İfade 7: Bu okul benim sadakatimi hak ediyor.

\section{Normatif Bağgll lık}

İfade 1: Başka bir iş ayarlamadan önce bu okuldan ayrılmaktan korkuyorum.

İfade 2: Bu okuldan ayrılmanın olumsuz sonuçlarından biri de, yeni iş alternatiflerinin azlığıdır.

İfade 3: Bu okuldan ayrılırsam hayatım alt üst olur.

İfade 4: Bu okuldan ayrılsam bile kısa bir sürede iyi bir iş bulmam benim için çok zor olurdu.

İfade 5: Bu okuldan ayrılmayı düşünmek için çok az tercih hakkına sahibim.

\section{Devamlılık Bă̆glılı̆̆l}

İfade 1: Bu okuldan ayrılsam suçluluk hissederim.

İfade 2: Bu okula çok şey borçlu olduğumu hissediyorum, ayrılırsam çok ayıp olur.

İfade 3: Bu okulda çalışan diğer insanlara karşı duyduğum sorumluluklar nedeniyle bu okuldan şimdi ayrılmam yanlış olacaktır.

İfade 4: Daha avantajlı olsa bile bu okuldan şimdi ayrılmak bana doğru gelmiyor.

İkinci faktör olan Örgüte Bağlılığın ilk alt faktörü olan "Duygusal Bağlılık" toplam varyansın \%36,301'ini açıklayan 7 ifadeden oluşmaktadır.

İkinci faktör olan Örgüte Bağllı̆̆ın alt faktörlerinden ikincisi olan "Normatif Bağlılık" toplam varyansın \%14,487'sini açıklayan 5 ifadeden oluşmaktadır.

İkinci faktör olan Örgüte Bağlılığın alt faktörlerinden üçüncüsü olan "Devamlılık Bağlılık” toplam varyansın \%5,611'ini açıklayan 4 ifadeden oluşmaktadır.

Tablo 5: İşten Ayrılma Niyeti Faktör Analizi Sonuçları

\begin{tabular}{|c|c|c|c|}
\hline $\begin{array}{l}\text { İşten Ayrılma } \\
\text { Niyeti }\end{array}$ & Faktör Yükü & Ortalama & $\begin{array}{l}\text { Açıklanan } \\
\text { Varyans }\end{array}$ \\
\hline İfade 1 & $-0,746$ & 3,73 & \multirow{5}{*}{$\% 49,161$} \\
\hline İfade 2 & 0,657 & 3,11 & \\
\hline İfade 3 & $-0,702$ & 3,36 & \\
\hline İfade 4 & 0,717 & 2,97 & \\
\hline İfade 5 & 0,681 & 2,36 & \\
\hline
\end{tabular}

İfade 1: $\mathrm{Bu}$ işyerinde önümüzdeki yıllarda da çalışmak isterim.

İfade 2: Önümüzdeki yıllarda başka bir işyerinde çalışmayı düşünüyorum.

İfade 3: Önümüzdeki 5 yıl içinde bu işyerinden ayrılmayı istemiyorum.

İfade 4: Diğer yerlerde iş bulma olanağım olup olmadığını bakıyorum

İfade 5: Sık sık işten ayrılmayı düşünüyorum.

Üçüncü faktör olan "İşten Ayrılma Niyeti” toplam varyansın \%49,161'ini açıklayan 5 ifadeden oluşmaktadır. 


\subsection{Değişkenler Arası İlişkiler}

Çalışma kapsamında analize dâhil edilen değişkenler arasındaki ilişkiyi belirlemek amacıyla ilk önce üç ana değişken arasında (Tablo 3) daha sonra ise aralarında anlamlı bir ilişki saptanan psikolojik sözleşme ihlal algısı ve örgüte bağlılığın alt boyutları arasında (Tablo 4) korelasyon analizi yapılmıştır.

Tablo 6: Değişkenlere Ait Kolerasyon Analizi

\begin{tabular}{|c|c|c|c|}
\hline & $\begin{array}{l}\text { Psikolojik } \\
\text { Sözleşme İhlal } \\
\text { Algis }\end{array}$ & $\begin{array}{l}\text { Örgütte } \\
\text { Bağlll1k }\end{array}$ & $\begin{array}{l}\text { İşten } \\
\text { Ayrılma } \\
\text { Niyeti }\end{array}$ \\
\hline $\begin{array}{l}\text { Psikolojik } \\
\text { Sözleşme İhlal } \\
\text { Algisı }\end{array}$ & 1 & & \\
\hline $\begin{array}{l}\text { Örgütte } \\
\text { Bağlllık }\end{array}$ & $-0,632 * *$ & 1 & \\
\hline $\begin{array}{l}\text { İşten Ayrilma } \\
\text { Niyeti }\end{array}$ & $0,566 * *$ & $-0,603 * *$ & 1 \\
\hline
\end{tabular}

$* * \mathrm{p}<0,01$

Psikolojik Sözleşme İhlal Algısı ile İşten Ayrılma Niyetleri Arasında arasında pozitif yönde yüksek düzeyde anlamlı bir ilişki vardır $(\mathrm{r}=0,566 \mathrm{p}<0,01)$. Psikolojik Sözleşme İhlal Algısı arttıkça İşten Ayrılma Niyetlerinin de artığı gözlemlenmiştir. Psikolojik Sözleşme İhlal Algısı ile Örgüte bağlılık arasında negatif yönde yüksek düzeyde anlamlı bir ilişki vardır $(r=-0,632 \mathrm{p}<0,01)$. Psikolojik Sözleşme İhlal Algısı arttıkça Örgütsel Bağlılığın azaldığ1 gözlemlenmiştir. Örgüte bağl1lık ve İşten Ayrılma Niyeti boyutları arasında negatif yönlü ve yüksek düzeyde anlamlı bir ilişki vardır $(r=-0,603 p<0,01)$. Örgüte bağlılık arttıkça İşten ayrılma niyetinin azaldığı gözlemlenmiştir.

Tablo 7: Psikolojik Sözleşme İhlal Algısı ve Örgüte Bağlılığın Alt Boyutlarına Ait Kolerasyon Analizi

\begin{tabular}{|c|c|c|c|c|}
\hline & 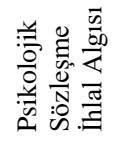 & 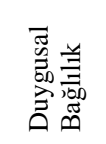 & 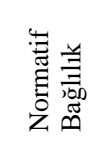 & 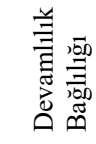 \\
\hline $\begin{array}{l}\text { Psikolojik } \\
\text { Sözleşme } \\
\text { İhlal Algisı }\end{array}$ & 1 & & & \\
\hline $\begin{array}{l}\text { Duygusal } \\
\text { Bağlilık }\end{array}$ & $\begin{array}{l}- \\
0,691 * *\end{array}$ & 1 & & \\
\hline $\begin{array}{l}\text { Normatif } \\
\text { Bağlılık }\end{array}$ & 0,029 & $-0,074$ & 1 & \\
\hline $\begin{array}{l}\text { Devamlılık } \\
\text { Bağlılığ }\end{array}$ & $\begin{array}{l}- \\
0,500 * *\end{array}$ & $0,496 * *$ & $\begin{array}{l}0,198 * \\
*\end{array}$ & 1 \\
\hline
\end{tabular}

Örgütsel bağlılığın alt faktörleri ile Psikolojik sözleşme ihlal algısı arasındaki kolerasyonu belirlemek amacıyla yapılan analizler sonucunda elde edilen sonuçlar şu şekildedir;

Psikolojik sözleşme ihlal algısı ile duygusal bağlılık ( $\mathrm{r}=$ $0,691 \mathrm{p}<0,01)$ ve devamlılık bağlılığ $(\mathrm{r}=-0,500 \mathrm{p}<0,01$ arasında negatif yönlü yüksek düzeyde anlamlı ilişki vardır. Psikolojik sözleşme ihlal algısı arttıkça örgüte duyulan duygusal bağlılığın ve devamlılık bağlılığının azaldığ gözlemlenmiştir. Ayrıca devamlılık bağlılığı ile duygusal bağlilık $(\mathrm{r}=0,496 \mathrm{p}<0,01)$ ve normatif bağlilık $(\mathrm{r}=0,198$ $\mathrm{p}<0,01)$ arasında pozitif yönlü anlamlı bir ilişki saptanmıştır.

Psikolojik sözleşme ihlal algı ile Normatif bağlılık arasında anlamlı bir ilişki saptanamamıştır. Bundan dolayı H4: "Psikolojik Sözleşme İhlal Algısının Normatif Bağlılık üzerinde negatif yönlü bir etkisi vardır” reddedilmiştir.

\subsection{Hipotezlerin Test Edilmesi}

Araştırma kapsamında hazırlanan hipotezlerin test edilmesi ve değişkenler arasındaki ilişkinin şiddeti ile ilişki yönünü belirlemek amaciyla basit doğrusal regresyon analizi yapılmıştır.

Tablo 8: Örgüte Bağlılık Faktörü ve Algılanan Psikolojik Sözleşme İhlalleri Arasındaki Regresyon Analizi

\begin{tabular}{|c|c|c|c|c|}
\hline & $R 2$ & $F$ & B & $p$ \\
\hline Model & \multirow{3}{*}{0,4} & \multirow{3}{*}{211,115} & & \\
\hline Sabit & & & 4.354 & 0.000 \\
\hline $\begin{array}{l}\text { Psikolojik } \\
\text { S. İ. A. }\end{array}$ & & & -0.459 & 0.000 \\
\hline
\end{tabular}

Bağımlı Değişken: Örgüte Bağlılık $* \mathrm{p}<0,05$

Algılanan Psikolojik Sözleşme İhlallerinde meydana gelen 1 puanlık artışın Örgüte bağlılık üzerinde (B)-0,459 puanlık bir düşüşe yol açtığ 1 görülmektedir. Elde edilen T değerinin her düzeyde anlamlılık göstermesi (Sig. = 000*) Algılanan Psikolojik Sözleşme İhlal Algısı değişkeninin istatistiksel olarak anlamlı bir katsayıya sahip olduğunu göstermektedir. Ayrıca Psikolojik sözleşme ihlal algısı, Örgüte bağlılı̆̆ın \%40'ını açıklamaktadır. Elde edilen bilgiler doğrultusunda H1: "Psikolojik Sözleşme İhlal Algısının Örgüte Bağlılık üzerinde negatif yönlü bir etkisi vardır" kabul edilmiştir.

Tablo 9: Duygusal Bağlılık Faktörü ve Algılanan Psikolojik Sözleşme İhlalleri Arasındaki Regresyon Analizi

\begin{tabular}{|c|c|c|c|c|}
\hline & $R 2$ & $F$ & $B$ & $p$ \\
\hline Model & \multirow{3}{*}{0,477} & \multirow{3}{*}{$289,0,70$} & & \\
\hline Sabit & & & 5.455 & 0.000 \\
\hline $\begin{array}{l}\text { Psikolojik } \\
\text { S. İ. A. }\end{array}$ & & & -0.769 & 0.000 \\
\hline
\end{tabular}

Bağımlı Değişken: Duygusal Bağlılık * $\mathrm{p}<0,05$

Algılanan Psikolojik Sözleşme İhlallerinde meydana gelen 1 puanlık artışın örgüte duyulan Duygusal Bağlılık üzerinde -0,769 puanlık bir düşüşe yol açtığı görülmektedir. Elde edilen $\mathrm{T}$ değerinin her düzeyde anlamlılık göstermesi (Sig. $=000 *$ Algılanan Psikolojik Sözleşme İhlalleri değişkeninin istatistiksel olarak anlamlı bir katsayıya sahip olduğunu göstermektedir. Ayrıca Psikolojik sözleşme ihlal algısı, Duygusal bağlılığın \%47,7'sini açıklamaktadır. Elde edilen bilgiler doğrultusunda H2: "Psikolojik Sözleşme İhlal Algısının Duygusal Bağlılık üzerinde negatif yönlü bir etkisi vardır" kabul edilmiştir. 
Tablo 10: Devamlılık Bağlılığı Faktörü ve Algılanan Psikolojik Sözleşme İhlalleri Arasındaki Regresyon Analizi

\begin{tabular}{|c|c|c|c|c|}
\hline & $R 2$ & $F$ & $B$ & $p$ \\
\hline Model & \multirow{3}{*}{0,25} & \multirow{3}{*}{105,008} & & \\
\hline Sabit & & & 4.042 & 0.000 \\
\hline $\begin{array}{l}\text { Psikolojik } \\
\text { S. İ. A. }\end{array}$ & & & -0.547 & 0.000 \\
\hline
\end{tabular}

Bağımlı Değişken: Devamlılık Bağlılığı $* \mathrm{p}<0,05$

Algılanan Psikolojik Sözleşme İhlallerinde meydana gelen 1 puanlık artışın örgüt içerisindeki Devamlılık Bağlılığı üzerinde -0,547 puanlık bir düşüşe yol açtığı görülmektedir. Elde edilen $\mathrm{T}$ değerinin her düzeyde anlamlılık göstermesi $($ Sig. $=000 *)$ Algılanan Psikolojik Sözleşme İhlalleri değişkeninin istatistiksel olarak anlamlı bir katsayıya sahip olduğunu göstermektedir. Ayrıca Psikolojik sözleşme ihlal algısı, Devamlılık bağlılığının \%25'sini açıklamaktadır. Elde edilen bilgiler doğrultusunda H3: "Psikolojik Sözleşme İhlal Algısının Devamlılık Bağlılığı üzerinde negatif yönlü bir etkisi vardır" kabul edilmiştir.

Tablo 11: İşten Ayrılma Faktörü ve Algılanan Psikolojik Sözleşme İhlalleri Arasındaki Regresyon Analizi

\begin{tabular}{|c|c|c|c|c|}
\hline & $R 2$ & $F$ & $B$ & $p$ \\
\hline Model & \multirow{3}{*}{0,32} & \multirow{3}{*}{149,272} & & \\
\hline Sabit & & & 1.333 & 0.000 \\
\hline $\begin{array}{l}\text { Psikolojik } \\
\text { S. İ. A. }\end{array}$ & & & 0.559 & 0.000 \\
\hline
\end{tabular}

Bağımlı Değişken: İşten Ayrılma Niyeti $* \mathrm{p}<0,05$

Algilanan Psikolojik Sözleşme İhlallerinde meydana gelen 1 puanlık artışın örgüt içerisindeki İşten Ayrılma Niyeti üzerinde 0,559 puanlık bir yükselişe yol açtığ1 görülmektedir. Elde edilen $\mathrm{T}$ değerinin her düzeyde anlamlılık göstermesi (Sig. $=000^{*}$ ) Algılanan Psikolojik Sözleşme İhlalleri değişkeninin istatistiksel olarak anlamlı bir katsayıya sahip olduğunu göstermektedir. Ayrıca Psikolojik sözleşme ihlal algısı, işten ayrılma niyetinin \%32'sini açıklamaktadır. Elde edilen bilgiler doğrultusunda H5: "Psikolojik Sözleşme İhlal Algısının İşten Ayrılma Niyeti üzerinde pozitif yönlü bir etkisi vardır" kabul edilmiştir.

\section{Tartışma}

$\mathrm{Bu}$ çalışma sonucunda elde edilen veriler Türkiye'de daha iyi bir üniversite eğitimi verilebilmesi için akademik personel ile üniversite yönetimi arasındaki ilişkinin değerlendirilmesine olanak sağlayabilecektir. Ayrıca daha önce yapılan benzer çalışma sonuçlarının incelenerek karşılaştırılmasına olanak sağlayabilecektir. Konu ile ilgili birçok çalışma bulunmasına karşın konunun akademik personel üzerindeki etkilerini belirlemeye yönelik çalışmaların azlığı göze çarpmaktadır.

Demiral (2008), psikolojik sözleşme ihlalleri ile örgüte bağlılık arasında anlamlı bir ilişki saptamıştır. Psikolojik sözleşme ihlalleri ile örgüte bağlılığın alt boyutlarından olan duygusal bağlılık, normatif bağlılık ve devamlılık bağlılık arasında anlamlı ilişkinin varlığını saptanmıştır. Büyükyılmaz (2014), psikolojik sözleşme ihlallerinin işten ayrılma niyeti üzerinde anlamlı bir etkisinin olduğunu belirlemiştir. Tipples, Krivokapıc-Skoko ve O’neil (2007),
Avusturalya ve Yeni Zelandalı akademisyenler üzerinde yaptıkları araştırmada psikolojik sözleşmelerin işyeri ilişkileri ve çalışan performansı üzerinde önemli bir etkisi olduğunu tespit etmiştir. Krivokapic-Skoko, ONeill ve Dowell ise akademisyenlerde psikolojik sözleşme ihlal algısının neden ve sonuçlarını incelemiştir. Çalışmaya göre, akademisyenlerde ihlal algıları arttıkça, öfke, ihanet ve kırgınlık duyguları belirmekte ve bu da sonuçta çalışan motivasyonunda, örgüte bağlılık, sadakat ve güven duygusunda azalmayla sonuçlanmaktadır.

Türkiye'de bulunan üniversitelerde görev yapmakta olan akademik personel üzerinde yapılan çalışmalarda elde edilen sonuçlar ile çalışmamız kapsamında elde ettiğimiz sonuçların örtüştüğü görülmektedir. Demiral (2008)'in çalışmasından farklı olarak bu çalışmada normatif bağlılık ile psikolojik sözleşme ihlal algısı arasında anlamlı bir ilişki saptanamamıştır.

\section{Sonuç}

Bu çalışma algılanan psikolojik sözleşme ihlallerinin örgüte bağlılık ve işten ayrılma niyeti üzerindeki etkilerinin belirlenmesi amacıyla akademisyenler ile yapılmıştır. Yapılan çalışmalar sonucunda algılanan psikolojik sözleşme ihlallerinin örgüte bağlılık ve işten ayrılma niyeti üzerinde anlamlı bir etkisi olduğu saptanmıştır. Ayrıca algılanan psikolojik sözleşme ihlallerinin örgütsel bağlılığın alt boyutlarından olan duygusal bağlılık ve devamlılık bağlılığı üzerinde anlamlı etkisi saptanmıştır fakat bir diğer alt boyut olan normatif bağlılık ile bir ile anlamlı bir etki saptanmamıştır.

Üniversitelerde eğitim kalitesinin sağlanmasında en önemli etkenlerden biri olan akademisyenlerin örgüte bağlılıklarının algılanan psikolojik sözleşme ihlalleri neticesinde düşüş göstermesi önemli bir noktadır. Bundan dolayı:

- Yönetim kademesinin bazı taahhütler vermeden önce bunların uygulanabilirliğine dikkat etmeleri,

- Akademisyenlere kariyer ilerlemeleri için gerekli teknik alanların oluşturulması,

- Akademik personel tarafindan yönetime verilen geri bildirimlerin dikkate alınması, başka bir ifadeyle katılmalı yönetim uygulanması,

- Akademik personelin kuruma karşı duyduğu aidiyet ve sadakatin dikkate alınması, işten ayrılma niyeti üzerinde negatif, örgüte bağlılık konusunda da pozitif bir etki gösterecektir.

Araştırma sonuçlarına dayanarak, örgütüne bağlı çalışanlara sahip olmak isteyen örgüt yöneticilerinin psikolojik sözleşme ihlallerinden kaçınmaları gerektiği söylenebilir. Araştırmanın Türkiye'de bulunan bazı üniversitelerde görev yapmakta olan akademisyenleri kapsaması çalışma adına bir kısıt olarak görülmektedir. Çalışmanın ilerleyen dönemlerde ulusal ve uluslararası düzeyde yapılabilecek benzer çalışmalar ile karşılaştırma yapılabilmesine olanak sağlayabileceği düşünülmektedir. Aynı şekilde çalışma, Türkiye'de bulunan diğer bölgelerde yapılacak olan çalışmalar ile kıyaslama yapılabilmesine yardımcı olabileceği ve çalışmanın ilerleyen tarihlerde aynı bölgede tekrarlanarak elde edilecek veriler ile kıyaslama 
yapılabilmesine olanak sağlayacağı düşünülmektedir. Bu şekilde gerek ulusal ve gerekse uluslararası çalışmalardan elde edilecek verilerin kıyaslanarak eğitim kalitesinin ve akademik personelin örgütsel bağlılığının arttırılması ile

\section{Kaynakça}

Argyris, C. (1960). Understanding Organizational Behavior, 3. Bask1, Dorsey Pres, Homewood, Illinois.

Aydın, İ., Memduhoğlu, H. B., Oğuz, E. ve Güngör, S. (2008) "Academic and Non-Academic Staff's Psychological Contract in Turkey" Higher Education Quarterly, 62(3): 252-272.

Bayram, L. (2005). Yönetimde Yeni Bir Paradigma: Örgütsel Bağlılık. Sayıştay Dergisi, (59), 125-139.

Bayram, L. (2005). Yönetimde Yeni Bir Paradigma: Örgütsel Bağlılık. Sayiştay Dergisi, (59), 125-139.

Büyükyılmaz, O., ve Cakmak, A. F. (2014). İlişkisel ve Işlemsel Psikolojik Sözleşmede Algılanan Ihlalin Işten Ayrılma Niyeti ve Algılanan Örgütsel Destek Üzerindeki Etkisi. Ege Academic Review, 14(4), 583596.

Cihangiroğlu, N., ve Şahin, B. (2012). Organizasyonlarda Önemli Bir Fenomen: Psikolojik Sözleşme. Uluslararası Yönetim İktisat ve İşletme Dergisi, 6(11), 1-16.

Çöl, G. (2004). İnsan Kaynakları Örgütsel Bağlılık Kavramı Ve Benzer Kavramlarla Ilişskisi, Işsüç The Journal Of Industrial Relations and Human Resources, 6(2), 411.

Dabos, G. E. ve Rousseau, D.M. (2004). Mutuality And Reciprocity İn The Psychological Contracts Of Employees and Employers, Journal Of Applied Psychology, 89 (1), 52-72.

Dağlı, M. (2016). Psikolojik Sözleşme Ihlalleri, Örgütsel Vatandaşlık Ve Örgütsel Adalet Algısı Ilişkisine Yönelik Bir Araştırma. Haliç Üniversitesi Sosyal Bilimler Enstitüsü İşletme Anabilim Dalı İşletme Programı. Yayınlanmış Doktora Tezi, İstanbul.

Demiral, Ö. (2008). Örgütsel Bă̆lılı̆̆ın Să̆lanmasında Personel Güçlendirme ve Psikolojik Sözleşmenin Etkisine Illişkin Bir Araştırma. Niğde Üniversitesi Sosyal Bilimler Enstitüsü, Yayınlanmamış Yüksek Lisans Tezi, Niğde.

Doğan, S., ve Demiral, Ö. (2009). Örgütsel Bağliliğin Sağlanmasinda Personel Güçlendirme ve Psikolojik Sözleşmenin Etkisine Ilişkin Bir Araştirma. Erciyes Üniversitesi İktisadi ve İdari Bilimler Fakültesi Dergisi, (32), 47-80. birlikte ișten ayrılma niyetlerinin azaltılması için gerekli bilimsel verilerin elde edilmesine olanak sağlayacağ düşünülmektedir

Durmuş, B., Yurtkoru, E. S., ve Çinko, M. (2016). Sosyal Bilimlerde Spss'le Veri Analizi. İstanbul: Beta Basım Yayın.

Durna, U., ve Eren, V. (2011). Üç Bağlılık Unsuru Ekseninde Örgütsel Bağlılık. Doğuş Üniversitesi Dergisi, 6(2), 210-219.

Eisen, M., Ware Jr, J. E., Donald, C. A., and Brook, R. H. (1979). Measuring Components Of Children's Health Status. Medical Care, 902-921.

Gakovic, A., and Tetrick, L. E. (2003). Psychological Contract Breach As A Source Of Strain For Employees. Journal Of Business and Psychology, 18(2), 235-246.

İşçi, E. (2010). Psikolojik Sözleşme Ihlalinin Örgütsel Vatandaşlık Davranışı ve Ișten Ayrılma Niyeti Üzerindeki Etkisinde Güvenin Rolü. Marmara Üniversitesi Sosyal Bilimler Enstitüsü İşletme Anabilim Dalı. Yayınlanmamış Doktora Tezi, İstanbul.

İyigün, N., Ö. (2011). Psikolojik Kontratın Örgütsel Sapma Üzerindeki Etkisinde Kişilik Özelliklerinin Rolü ve Bir Araştırma. Marmara Üniversitesi Sosyal Bilimler Enstitüsü İşletme Anabilim Dalı Yönetim ve Organizasyon Bilim Dalı. Yayınlanmamış Doktora Tezi, İstanbul.

Kaldırımc1, N. (1987). Motivasyon Için Anahtar Bir Kavram: Psikolojik Sözleşme. Erciyes Üniversitesi Sosyal Bilimler Enstitüsü Dergisi, 1(1), 113-128.

Karataş, S., ve Güleş, H. (2010). Ilköğretim Okulu Öğretmenlerinin Iş Tatmini Ile Örgütsel Bağl1lığg Arasındaki Ilişki. Uşak Üniversitesi Sosyal Bilimler Dergisi, 3(2), 74-89.

Karcıoğlu, F., ve Türker, E. (2010). Psikolojik Sözleşme Ile Örgütsel Bağlılık Ilişkisi: Sağlık Çalışanları Üzerine Bir Uygulama. Atatürk Üniversitesi İktisadi ve Idari Bilimler Dergisi, 24(2), 121-140.

Kayış, A. (2017). Güvenirlilik Analizi. Ş. Kalaycı Içinde, Spss Uygulamalı Çok Değişkenli Istatistik Teknikleri Ankara: Dinamik Akademi Yayın.

Kotter, J. (1973). The Psychological Contract: Managing The Joining-Up Process, California Management 15(9), 91- 99.

Krivokapic-Skoko, B., O’Neill, G. and Dowell, D. (2011). Academics and Breach of The Psychological Contract In The University Sector: Insights From An Australian Business School, Bam2011: Building and Sustaining High Performance Organisations İn A Challenging Environment, British Academy of Management (Bam) Annual Conference, (13-15 September 2011).

Meyer, John P. and Natalie J. Allen (1996). Affective, Continuance and Normative Commitment To The The Organization: An Examination Of Construct 
Validity, Journal Of Vocational Behavior, 49:252276.

Morrison, D. E. (1994). Psychological Contracts and Change. Human Resource Management, 33(3), 353372.

Morrison, E. W. and Robinson, S. (1997). When Employees Feel Betrayed: A Model Of How Psychological Contract Violation Develops, Academy of Management Review, 22(1), 226-256.

Orvis, K.A., Dudley, N. M. ve Cortina, J. M. (2008) "Conscientiousness and Reactions to Psychological Contract Breach: A Longitudinal Field Study" Journal of Applied Psychology, 93(5): 1183-1193.

Özgen, H. M., ve Özgen, H. (2010). Psikolojik Sözleşme ve Boyutlarının Iş Tatmini Örgütsel Bağlılık ve Işten Ayrılma Niyetine Etkileri: Tibbi Satış Temsilcileri Üzerinde Bir Araştırma. Çukurova Üniversitesi Sosyal Bilimler Enstitüsü Dergisi, 19(1).

Özler, D. E., ve Ünver, E. (2012). Psikolojik Sözleşmenin Iş Tatmini Üzerindeki Etkisini Belirlemeye Yönelik Bir Araştırma. Süleyman Demirel Üniversitesi İktisadi ve İdari Bilimler Fakültesi Dergisi, 17(2).

Özyılmaz, D. (2016). Ikibinli Yıllarda Işgücü Piyasalarında Meydana Gelen Dönüşümün Eğitimli Gençlerin Istihdam Kararlarında Yarattı̆̆ Değişim: Bilişsim Sektörü Uygulaması. Gazi Üniversitesi Sosyal Bilimler Enstitüsü Çalışma Ekonomisi ve Endüstri İlişkileri Anabilim Dalı Çalışma Ekonomisi ve Endüstri İlişkileri Bilim Dalı. Yayınlanmamış Doktora Tezi, Ankara.

Polat, M., ve Meydan, C. H. (2010). Örgütsel Özdeşleşmenin Sinizm ve Işten Ayrılma Niyeti Ile Ilişkisi Üzerine Bir Araştırma. Savunma Bilimleri Dergisi, 9(1), 145172.

Poyraz, K., ve Kama, B. (2008). Algılanan Iş Güvencesinin, Iş Tatmini, Örgütsel Bağlılık ve Işten Ayrılma Niyeti Üzerindeki Etkilerinin Incelenmesi. Süleyman
Demirel Üniversitesi İktisadi ve İdari Bilimler Fakültesi Dergisi, 13(2), 143-164.

Robinson, S. L., and Rousseau, D. M. (1994). Violating The Psychological Contract: Not The Exception But The Norm. Journal Of Organizational Behavior, 15(3), 245-259.

Robinson, S. L., and Morrison, E. W. (1995). Psychological Contracts and OCB: The Effect Of Unfulfilled Obligations On Civic Virtue Behavior. Journal Of Organizational Behavior, 16(3), 189-298..

Sekaran, U. (2003). Research Methods For Business: A Skill Building Approach, 4th Edition, New York: John Wiley \& Sons.

Starnes, B. J. (2007). An Analysis Of Psychological Contracts In Volunteerism and The Effect Of Contract Breach On Volunteer Contributions To The Organization. The International Journal Of Volunteer Administration, 14(3), 31-41.

Tipples, R., Krivokapic-Skoko, B., and O'neill, G. (2007). University Academics' Psychological Contracts İn Australia and New Zealand. New Zealand Journal Of Employment Relations, 32(2), 32-52.

Torun, A., ve Üçok, D. (2014). Tükenmişliği Etkileyen Olumsuz Tutum ve Beklentiler: Sinik Tutum ve Psikolojik Sözleşme Ihlali Algısı Üzerine Bir Araştırma. Atatürk Üniversitesi Íktisadi ve İdari Bilimler Dergisi, 28(1).

Yaşlıŏlu, M. M. (2017). Sosyal Bilimlerde Faktör Analizi ve Geçerlilik: Keşfedici ve Doğrulayıcı Faktör Analizlerinin Kullanılması. Ístanbul Üniversitesi İşletme Fakültesi Dergisi, 46, 74-85.

Y1lmaz, A. (2012). Psikolojik Sözleşme ve Örgütsel Güven Arasındaki İlişkinin Analizi: Teorik ve Uygulamalı Bir Çalışma. Selçuk Üniversitesi Sosyal Bilimler Enstitüsü İşletme Anabilim Dalı Yönetim ve Organizasyon Bilim Dalı. Yayınlanmamış Yüksek Lisans Tezi, Konya. 